\title{
More Than Preaching to the Choir: Religious Literate Activity and Civic Engagement in Older Adults
}

\section{Annie Kelvie - University of Illinois at Urbana-Champaign}

\author{
KEYWORDS \\ religious literacies; civic engagement; older adult literacies; progressive Christianity; \\ community literacy; race
}

\begin{abstract}
"During one of our Pub Theology sessions as we were talking about this service, one of us, probably me said, 'But I feel like I'm preaching to the choir!' And then someone else in the group shared some brilliant insight saying, 'But we're the choir too. We thought we knew this stuff, but we didn't."'
\end{abstract}

--Tom, church member and IT professional

"The question is one of both strategy and principle: Do you win by chasing those who don't share your views, or by serving and respecting those already with you? Is the purpose of the choir to sing to the infidels or inspire the faithful? What happens if the faithful stop showing up, donating, doing the work?"

--Rebecca Solnit, essayist, "Preaching to the Choir"

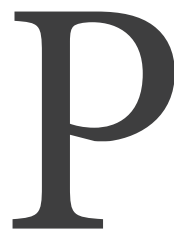

$\mathrm{ub}$ Theology is admittedly a strange moniker for a church book group that neither meets in a pub nor discusses theology books very often. Nevertheless, this group of committed older adult readers has been meeting weekly in their church's common room on Monday evenings for about six years: catching up on each other's lives, voting on new book selections, giving each person who comes a chance to speak, and munching on plenty of popcorn during the discussion. The meetings are often a highlight of members' weekly routines, a friendly way of enjoying books and socialization. ${ }^{1}$ However, an unfamiliar sense of urgency visited the group in fall 2015 when they started reading Michelle Alexander's The New Jim Crow: Mass Incarceration in the Age of Colorblindness and continued into the following year when they read Bryan Stevenson's Just Mercy: A Story of Justice and Redemption. Both books highlight the severe disparities in how criminal justice is meted out to communities of color in America, arguing for systemic change to right these long-term wrongs. For the first time in the group's history of reading and learning together, they were unsettled enough to feel like they had to act on what they were reading. Part of that action, as a group, included writing and presenting an entire church service about the subject matter of the books: the relationship between racism and the American criminal justice system.

Tom, quoted in the opening epigraph, aptly illustrates the dilemma the book group faced 
when deciding to present this information from the pulpit: the group belongs to what he calls a "pretty liberal" church. The group did wonder if their efforts "preaching to the choir" would be better spent educating those who more vehemently disagree with them. As Rebecca Solnit points out in her November 2017 essay, "Preaching to the Choir," the phrase has become shorthand for useless pronouncements of in-group virtue, to staying put within one's own ideological bubble and not venturing outside of it. Stereotypes of older people as being rigid in their thinking and unwilling or unable to learn the use of new technologies and new ideas seem to dovetail with our worst impressions of preaching to the choir: repeating the same timeworn clichés to those who already agree, not bothering to changing anyone's mind. It would seem that preaching to the choir, especially when done by older people, could easily be dismissed within a larger cultural ideology of decline and irrelevance, an activity that older people putter around with while the "real work" of social change is accomplished by the young.

However, as both Solnit in her essay and Tom in his sermon point out, preaching to the choir is a completely necessary activity for both solidarity-building and more in-depth learning. In this particular case, a group of mostly white, middle-class older adults realized that their own beliefs and assumptions about race could stand to be challenged and improved despite thinking of themselves as part of the choir of liberal or progressive people. In order to be able to do something as apparently simple and repetitive as "preaching to the choir," these older adults built upon religious, personal, and professional literacies in order to create shifts in their own values and actions, and hopefully persuade others to shift their own values and actions. In this article, I argue that the members of the Pub Theology book group push back against the isolation and individualism that decline ideology foists upon older people, and instead create a robust model of civic engagement rooted in literate activity among older adults. These older adults draw on familiar genres and literate practicesconsuming daily local news, participating in church services, and writing in the workplace-to change their perspective on race in the criminal justice system and encourage others to do the same.

\section{Literature Review: Civic Engagement as a Common Thread}

There has not been much scholarship that examines the interplay between religious literacies and age studies. However, within both of these subfields, civic engagement is a topic of great interest. This section briefly overviews the scholarly conversations about civic engagement within religious literacy scholarship and conversations about civic engagement within age studies with an eye toward the goal of bringing these two conversations together as they play out in the lives of my participants. To begin, though, I must acknowledge that the definitions of civic engagement as a term are manifold, depending on who is deploying the term and to what end, as Richard P. Adler and Judy Goggin point out in their aptly-titled piece, "What Do We Mean by Civic Engagement?" With that in mind, I use communications scholar Michael Delli Carpini's capacious definition of civic engagement: "individual and collective actions designed to identify and address issues of public concern" (qtd. in Adler and Goggin 239). This more open conception of civic engagement stands in contrast to how the term is popularly deployed in discussions of older people, as will be shown later in this section. 
Scholarship about the relationship between religious rhetoric and civic engagement was reinvigorated with the publication of Sharon Crowley's Toward a Civil Discourse: Rhetoric and Fundamentalism in 2006. Crowley shows how right-wing apocalypticist Christian rhetoric functions within a densely articulated ideologic that starkly mismatches liberal democratic values and attitudes, leading to a breakdown in conditions that allow democratic deliberation to effectively work. Some have critiqued Crowley's book for her portrayal of the religious rhetor as a uniquely static type of person who is completely unwilling and unable to change (DePalma et al.). This discourse of mismatch between the religious rhetor and the secular liberal rhetor carries over into the field's pedagogical scholarship as well, the mismatch usually framed as occurring between an evangelical Christian student and a secular liberal professor in a first-year composition classroom (e.g., Downs; Worth). In response to these mismatch arguments, Jeff Ringer has shown the complex and nuanced rhetorical practices utilized by evangelical students as they make arguments about civic topics ("Consequences" and "Working"), and Michael DePalma has argued that professors should consider religious commitment as a rhetorical resource for fostering civic engagement, giving examples from and analyses of syllabi in the field that do this work ("Reimagining" and "Re-envisioning"). Most of these works address the rise of conservative Christian civic engagement in the US since the 1980s, but an important exception has been in studies involving literacies taught in predominantly African-American churches, which have long served as a staging ground for progressive causes and community empowerment (e.g., Brandt; Moss).

Beth Daniell writes in her 2015 piece "More in Heaven and Earth: Complicating the Map and Constituting Identities" that because the field has been so focused on the apocalypticist Christian Right, its map of religious literate engagement is problematically small. She writes, "This map leaves no room for those who may hold liberal political views while practicing their faith or for those who, while socially conservative, experience a Christian community focused on compassion and forgiveness" (243). Following Daniell's call to complicate the map of Christian rhetorics within the field, the data for this article come from a larger study that focuses on religious literate activity inside churches that specifically label themselves as progressive. Many of the main questions driving my larger study of these progressive church field sites dealt with civic engagement: In what ways does religious literate activity inform the civic engagement of its members? How do rhetorical and literate practices performed at a progressive church influence the social and political causes with which they involve themselves? What types of arguments persuade these believers when it comes to social and political issues?

As I did fieldwork within this church, it became clear that the Pub Theologians were quite absorbed in connecting their faith to civic engagement due to their readings. Then, after finding myself on the receiving end of a few (gentle) jokes from the Pub Theologians about being the youngest person in the room by quite a bit, I started to notice and consider more fully the older age of all of the group's members. There were jottings in my field notes of one group member's reflection on her recent seventieth birthday, another of a lively discussion of who was planning to retire when and their feelings about it. It is worth noting that that the vast majority of older people in the US identify as being religious and part of a particular religious tradition, whether that tradition is conservative 
or liberal. In a Public Religion Research Institute survey conducted in 2014, only 11\% of Americans aged sixty-five and older and only $16 \%$ aged fifty to sixty-four said they were religiously unaffiliated (rpt. in Jones 48). It follows then, that understanding the literate lives of older Americans should involve a significant dive into their religious literate activity in all its complexity. I found with this group that age, religion, and race are not strands that can easily be separated from one another when analyzing how these group members interacted with their chosen texts and created texts of their own.

Scholars in age studies have drawn attention to the dichotomy between "decline ideology" and "productive aging" in models of aging, and that dichotomy directly affects cultural conceptions of how older people civically engage and why. Decline ideology is most thoroughly described by Margaret Morganroth Gullette in her book Aged by Culture, which she then expands upon in her later works. She presents decline ideology as a way of thinking about the life course that idealizes a rather short period of time in young adulthood where a person is considered at his or her "peak" or "prime," intellectually and physically. Then, a long decline with its attendant loss of physical prowess, intellectual sharpness, and professional success, settles in as early as one's thirties or forties, leaving one with many decades to look back nostalgically on that very short young adulthood "peak." (Aged 130-2). To be clear, Gullette does not actually believe that decline is a universal phenomenon, but she instead points out the countless venues where decline ideology is naturalized and reified to the point that it functions as an objective truth in American society. She writes:

Decline is a metaphor as hard to contain as dye. Once it has tinged our expectations of the future (sensations, rewards, status, power, voice) with peril, it tends to stain our experiences, our views of others, our explanatory systems, and then our retrospective judgments. . . . One of decline's saddest egocentripetal effects is to obscure anything suffered by those adjacent to us, in the polity and across the globe. The only history that matters is that of our times. Decline then squeezes the life span further, into an inflexible, biological, individual arc. (Aged 11)

In other words, even though decline functions more as a metaphor than as a universally true phenomenon, the negative effects of our belief in the truth of the metaphor do real damage, especially insofar as that belief isolates older people and makes their world smaller. One of the major negative effects of decline ideology, Gullette contends, is the simultaneous invisibility and hypervisibility of older people, depending on the context in which the figure of the older person is encountered (Ending xxi).

An illustration of this dichotomy between the hypervisibility and invisibility of older people plays out in how the political involvement or civic engagement of older people is described and reported. Older citizens are often referred to as being selfish, egocentripetal, as in the famous "greedy geezer" stereotype that was popularized in the 1980s, a stereotype that pops up regularly in thinkpieces and articles to this day. In this narrative, older people are hypervisible as they purportedly hoard scarce resources and care only for themselves at the expense of the young (Martinson and Halpern 428). Decline ideology also positions older people as enemies of change, even though scholars looking at the relationship between age and social movements, like Olivier Fillieule, have noted that "serious 
doubts have been cast on the notion that with old age comes political disengagement or growing conservatism on political issues" (2).

In what is perhaps a well-meaning attempt to de-center decline ideology and greedy geezer stereotyping, the case has been made for "productive aging," which usually involves wellness regimens (Spindler) and encouragement for older Americans to be more civically engaged after retirement, usually through structured and regularly scheduled volunteer work (Adler and Goggin). In this model of aging, older people become invisible—compliant and eager to "earn their keep" by working for free. While advocates for the civic engagement of older citizens usually cite the endless benefits of volunteerism, critical gerontologists Marty Martinson and Meredith Minkler are among a growing handful of scholars who argue that conflating the terms "civic engagement" and "volunteerism" for older adults is harmful for a number of reasons, most of all because it devalues those older people who are either unable or unwilling to provide free labor once they have stopped working at their careers. They also point out that " $[\mathrm{w}]$ hen civic engagement is reduced to the act of formal volunteering, other activities associated with civic life, including voting, engaging in community activism, staying informed about current events, caregiving, and having informal connections, are notably ignored" (319). In other words, the productive aging model can be just as constraining as decline ideology, albeit in a different way.

Between the isolating nature of decline ideology and the questionable ethics of pushing all older people towards free labor, it becomes clear that there is a need for accounts of how older citizens can and do participate meaningfully in civic life. My findings suggest that through their literate activity, the Pub Theologians civically engage in a space between the rigidity of a decline narrative and the mandates of productive aging. To use Gullette's language, they avoid the "egocentripetal effects"

"My findings suggest that through their literate activity, the Pub Theologians civically engage in a space between the rigidity of a decline narrative and the mandates of productive aging....Instead of being obsolete and useless, their familiar literate practices are crucial to connecting what they learned from their chosen texts to more expansive experiences of civic engagement as older members of their community." inherent in a decline model of aging, becoming emotionally engaged in what those adjacent to them are suffering. Instead of being obsolete and useless, their familiar literate practices are crucial to connecting what they learned from their chosen texts to more expansive experiences of civic engagement as older members of their community.

\section{Methods}

My findings come from a larger IRB-approved study conducted at an active congregation of the United Church of Christ in a medium-sized Midwestern city. The United Church of Christ is a theologically liberal, mainline denomination with about one million members nationwide. The church as a whole had about 100 in attendance on a given Sunday during the time the bulk of data 
for the study was collected; and church members are a mix of ages, and at the time of fieldwork the congregation was mostly white. While the Pub Theology group does not have a formal membership roll, the number of people attending remained fairly consistent throughout my fieldwork. Figure 1 lists the regularly attending group members and their roles in the culminating Sunday service.

\begin{tabular}{|c|c|c|}
\hline Participant Name ${ }^{2}$ & Profession & Involvement with Sunday Service \\
\hline Tom & IT specialist & $\begin{array}{l}\text { Wrote and presented sermon portion } \\
\text { "What We Learned" }\end{array}$ \\
\hline Jeanne & Elementary teacher & $\begin{array}{l}\text { Wrote "Further Ways to Get Involved" } \\
\text { handout }\end{array}$ \\
\hline Michael & Partially retired, therapist & $\begin{array}{l}\text { Wrote and presented Prayer of Confession, } \\
\text { Call to Worship, and Benediction prayers }\end{array}$ \\
\hline Mary & Unknown & Attended \\
\hline John & Unknown & Attended, handed out communion \\
\hline Sue & Partially retired, Doula & Attended, handed out communion \\
\hline Lou & Retired, therapist & $\begin{array}{l}\text { Wrote and presented introduction to Bible } \\
\text { reading, "StoneCatchers" }\end{array}$ \\
\hline Becky & Retired, unknown & Attended \\
\hline Jan & Retired, unknown & Attended \\
\hline Teresa & $\begin{array}{l}\text { Retired, academic } \\
\text { professional }\end{array}$ & Attended, handed out communion \\
\hline Pat & Nurse and nurse educator & $\begin{array}{l}\text { Wrote and presented sermon portion } \\
\text { "How We Changed" }\end{array}$ \\
\hline Harvey & $\begin{array}{l}\text { Public defender and } \\
\text { criminal defense attorney }\end{array}$ & $\begin{array}{l}\text { Wrote and presented sermon portion } \\
\text { "What We Can Do" }\end{array}$ \\
\hline Anita & Businesswoman & Attended, handed out communion \\
\hline
\end{tabular}

Table 1. Pub Theology Regular Participants.

Of the thirteen regular members, twelve were white and one was African-American. At the service planning meetings, five of the thirteen regular members volunteered to write original material that would be presented to the entire congregation. However, all members of the group participated in the group's lively conversations, some of which directly appeared in the service. Group members also provided feedback on drafts of the writers' texts as well as behind-the-scenes organization and support for the event.

The methodology for this study foregrounds literate activity, as described by Paul Prior, who writes, "Literate activity, in this sense, is not located in acts of reading and writing, but as cultural forms of life saturated with textuality, that is strongly motivated and mediated by texts" (138). Because a literate activity framework positions writing as situated, mediated, and dispersed, it is essential to use research methods that capture more than just a final textual product. The materials I analyzed 
for this article included ethnographic observation field notes, transcripts of meetings, drafts of texts written for and based on the church service, and text-based interviews. Three out of the five primary service writers agreed to be interviewed three months after the service was conducted to give them time to reflect on how their ideas settled internally for each writer personally, as well as how the ideas settled in the congregation. The interviews I conducted with the writers were semi-structured as well as text-based (Odell, Goswami, and Herrington). In text-based interviews, the interviewer brings a copy of the writer's work to specifically guide the questions to the manuscript, allowing the writer to discuss the significance of particular choices he or she made during the writing process.

Rather than beginning analysis with a pre-determined set of codes, I used open coding as my initial method when working with this wide range of participant manuscripts, meeting and interview transcripts, and field notes (Strauss). I also drew on tenets of Kathy Charmaz's grounded theory approach to qualitative research, namely its commitment to centering practices that participants find important and an emphasis on collecting and analyzing data simultaneously in a recursive process (2-3). This approach proved fruitful when I noticed that group members did not spend as much time discussing the assigned texts as I thought they would, instead frequently connecting the concepts from the texts to what was happening in their own community. Since this was a practice that seemed important to the group, I then began to code for patterns related to intertextuality in their discussions, writings, and interviews. As Charles Bazerman writes, "intertextuality often seeks to create a shared understanding of what people have said before and what the current situation is. That is, intertextual reference can attempt to establish the social facts upon which the writer is attempting to make a new statement" (313). Since the Pub Theologians underwent a process of re-negotiating their own social facts about race and criminal justice (i.e., moving from believing the system is inherently fair and works well for everyone to acknowledging and working against racial disparities in that system), instances of intertextuality became relevant to understanding how and where they had changed their ways of thinking about this issue of civic importance. I also coded for the genres, or typified oral and written communication patterns (Bazerman 316-8), that the Pub Theologians used most frequently and for how they interpreted those generic conventions and eventually chose to deploy them in their Sunday service.

\section{"I Bet None of Us Reads the Paper the Same Way": Daily Literate Activity and Civic Engagement}

One of the more insidious effects of the decline narrative as it pertains to the literacies of older people is that it assumes that older people's literacies and literate practices only stagnate and decline. Much of the work about older people within literacy and composition studies has shown how older people have a much more complex and nuanced relationship with their literacies than decline ideology would allow, whether it is learning the use of new literate technologies (Bowen) or using the literacies they already cherish to shape a meaningful path through the end of their lives (Rumsey). Building on that work, I show in this section how the Pub Theologians use habitual literate practices as a vehicle for significant change. Reading and discussion of local news stories as they connected 
to their book selections drew individual members closer together as a group. Their religious literate practices also drew them into caring about issues that did not directly affect them personally, in contrast to the greedy geezer stereotype, which presumes that older people only care about their own benefits and bank accounts. At most meetings, someone would bring up an article from that week's newspaper, and the discussion would center more around making intertextual connections between the newspaper and the books rather than just close reading the assigned chapters. All participants were familiar with The Daily Tribune, and the following interaction about content found in this shared text was typical. The group begins to discuss a story about a young African-American male getting pulled over for failing to use a turn signal that ended in his arrest on a drug charge.

Michael: I bet none of us reads the paper the same way we did six months ago.

Anita: Oh my gosh.

Tom: (louder) You know, that is [so true! $]^{3}$ I find myself=

Teresa: [Absolutely]

Anita: Did you see the paper today?

Tom: I find myself=

Anita: $=$ There was something in the paper today that was right on point with this book.

Tom: I find myself when I look at the police blotter or the stories about so and so, I, you are so right Michael, I am now reading that wondering as you were, when we were going around about okay, what's the backstory here that isn't being reported?

Anita: In the paper today there was this article that I thought, oh my gosh. It was just a small, I don't know if you saw it, about the guy that didn't use his turn signal.

Michael: Right.

As noted by the overlapping turns and volume of delivery, the Pub Theologians were often quite animated and threw themselves in the discussion wholeheartedly when talking about situations from the newspaper that went along with the situations that were described by the authors of their books. As a repeated type of talk at meetings, discussions of local current events served to solidify social bonds between group members, as these discussions were often the ones that got the whole large group involved in the conversation at once. 
Anita then went on to explain her thought process as she read the article to the whole group, quoted below.

But what he stopped him for was failure to use a turn signal and my first thought was, okay, was he turning left which was a major problem? Was he just changing lanes and you know how sometimes you just pull over and don't use, you know? What was the story here... So you're right, when you say you read the paper now, you don't read it the same, that's exactly what, when I saw that article, 'Failure to Use Turn Signal Stop' and it turned into this big drug bust, I thought, that is our book, right there in the Daily Tribune.

In this turn of the conversation, Anita summarizes the connections she made not only between the book and the newspaper article, but also between her own experience of driving and how it differs from the young black man in the article. Anita's comment about how she had switched lanes without using a turn signal without the same consequences is also representative of how many of the group members changed throughout their time discussing these articles and books: putting themselves in the described situations and noticing that their outcomes had been quite different. Most of the Pub Theologians said at various points over these months that they had not previously thought about, much less empathized with, people labeled as criminals or felons. But, as they read the books and then connected those stories to what was happening in their local community, their beliefs shifted. The Pub Theologians had always been avid newspaper readers, but their rather dramatic shift in focus and concern when reading was a big change, illustrating how interactions with very familiar texts can be shifted over the long course of a life. Instead of being a stagnant literate practice, the ordinary repetition of daily newspaper reading ended up serving as a regular point of connection to and reinforcement of the new ideas that the group members first encountered in The New Jim Crow and Just Mercy.

\section{"We Must Educate, Congregate, and Agitate": Emotion and Persuasion within the Familiar Genre(s) of the Sunday Service}

One of the recurring concerns of the Pub Theologians as they discussed these particular books was that of processing difficult emotions. As a result, during their planning and writing meetings as they composed their service, they often discussed how they wanted the congregation to feel as a result of their performance: moved to action, but not judged or attacked. In this section, I will show how the Pub Theologians used their long-standing knowledge of the genre conventions as practiced at this church in order to compose a service that both comforts and challenges their fellow churchgoers to feel and think differently about racism and the criminal justice system. Their efforts with this church service are especially relevant to extending arguments like Martinson and Minkler's, that civic engagement as practiced by older people should not be limited simply to providing free volunteer labor wherever someone else decides it is needed. Instead, the church gives the group members the space and the visibility necessary to deploy their civic-minded literacies in a selfdirected manner. The Pub Theologians are able to remediate the content of their books into the shared genres of how God is worshipped in this community, and in so doing, find a way to engage 
their fellow churchgoers with a topic they previously may have ignored.

One of the main genres present in Sunday services at the church besides the sermon is group prayer, or the direct address of God by the congregation as they read from their weekly bulletins in unison. The exact text of these prayers varies from church to church, but it usually contains a statement of the collective sins that churchgoers have committed throughout the week for which they seek forgiveness from God ("Book of Common Prayer"). While many Christian churches use the Prayer of Confession on a weekly basis, this church chooses not to use it as frequently, alternating it with other types of prayers so as not to focus only on sin. Because the group chose to include a confession of sin that was related to their reading, they needed to write one themselves. Michael, a regular and enthusiastic participant in weekly Pub Theology meetings who nonetheless took care to describe himself as "not very religious," was the first to volunteer to write the prayer of confession for the Sunday service. He stuck to the genre's conventions as typically practiced in this church setting, basing his prayer on the way that the church's longtime former minister, Rev. Jack Good, would write and deliver his prayers of confession. In an interview, Michael explained, "When [Rev. Good] would do the prayer of confession each week specifically, it was thirty years ago, twenty-five or thirty years ago. Sunday after Sunday, I would just be mesmerized. Often teary... Something about the way he did that, framed that, just got that. And so I knew I wanted write the Call to Confession." For Michael, the repetition of the genre, "Sunday after Sunday," served as a point of significance rather than stagnation. Since the genre had been so emotionally resonant for him, he was especially concerned that the prayer he wrote would likewise evoke an emotional response in his audience.

The following is an excerpt from the final version of the prayer that Michael wrote and then led from the podium at the front of the church and the congregation at their Sunday service.

Michael: Let's join together in our confession. God who steadfastly seeks wholeness, even as we try to break things how can this be?

Congregation: How can this be? How can we have done this? How can we have overlooked this?

Michael: We're ashamed of our silence. In Your name we agreed to notice hatred and we didn't. And so we are here in this quiet place to cry out, who can treat another person like they're invisible? Who can hold someone down until they cannot breathe? Who can imprison another spirit in poverty or in discrimination?

Congregation: We can. We did. If only by our silence, we do.

In keeping with the traditional form of a Prayer of Confession, the congregants take responsibility for their wrong actions, sin, and also the things they have left undone that potentially could have made the world a better place. Remediating this long-established tradition of accounting for silence and inaction as being sinful and wrong, Michael is then able to name staying silent and inactive about 
racism as also being sinful and wrong. As scholars like Deborah Mutnick have noted in the pages of this journal, contemporary colorblind ideologies that present American racism as an anomaly from the past make it difficult for people to discuss the topic at all, whether in the college classroom or at church (73). Present-day American cultural notions of being racist usually involve saying something overtly racist, and Mutnick and other scholars (e.g., Trainor, "Critical," "My Ancestors," "Rethinking Racism"; Winans) have described how white people who do not participate in such overt behaviors are often very resistant to thinking about themselves as being racist. By drawing intertextual connections between the ideas in their books and the patterns of confessional prayer as practiced in this church community, Michael draws on years of shared language to persuade fellow white church members to take up what may be an unfamiliar or troubling idea.

When discussing the writing process of the prayer in an interview following the service, he discussed the significance of the choice he made when writing the first series of questions asked by the congregation. He explained, “To say 'How can that happen?' is too empty. It's more like, 'How could we let that happen, we as the people of compassion, as some would say, the people of God?' How could we have just turned aside and not known this?" Over the course of their time spent on these books, the Pub Theologians

"He invites them to admit out loud that racism and mass incarceration are something they are involved in, which is no small feat in an American culture steeped in colorblind ideologies." became closer not only to the suffering of their fellow citizens but also to the ways that they themselves had helped prolong that suffering, if only through their ignorance. In moving from the impersonal "How could this happen?" to "How could we let that happen?" Michael pushes the largely white congregation to make the same shift towards recognizing their own role in that suffering that Pub Theology members did. He invites them to admit out loud that racism and mass incarceration are something they are involved in, which is no small feat in an American culture steeped in colorblind ideologies.

Although Michael stayed largely within the familiar genre conventions of a typical Prayer of Confession, the group decided to completely forego another recurring genre within the Sunday service, that of the "special offering," again in hopes of having a specific emotional effect on their audience. This church usually holds a few themed services each year about social issues like hunger or refugees. After learning about a given issue during the service, the money taken up that week is given to a related charity. The charity is usually written about in the bulletin and spoken about from the pulpit, and this action is a way for the people sitting in the pews to participate immediately in helping those affected by that week's issue. Even though this group had not put on a themed service of their own before, they were familiar enough with the genre to know that it is a common practice and would probably be expected by their audience. The following interaction occurred during a planning meeting, right after Lou simply asked where the special offering money would go, as she assumed they would take up this genre convention: 
Michael: One thing quoting Michelle Alexander now, or thinking about her, what we don't want to do is end, after the service, is get people off the hook.

Tom: Oh for sure.

Pat: Oh God, yes.

Michael: So I put money in a special offering, done.

Tom: Right.

Anita: Oh no.

Pat: That's a good point.

Tom: That's a good point. No, what we want to do is inspire them to [do more.]

Michael: [They need] to think and suffer like we did.

Pat: And suffer (laughter) like we did.

Michael: I'm serious.

Tom: Because [we did]

Mary: [And struggle] with it

Tom: There were times we did.

This excerpt again shows their attunement to the emotional experience of the congregation being one of the most important aspects of the service. After a little more conversation, the group decided to eliminate the familiar and comforting action of the special offering. Instead, Jeanne put together (with the help and input of most group members in an email chain) a detailed insert in the bulletin that included a bibliography of books and documentaries, local racial and prison justice organizations to volunteer time with, and upcoming community events to attend. The handout Jeanne compiled also gestures to a richer conception of civic engagement than either just giving money or signing up for regular volunteer hours. While the organizations listed were happy to receive donations or regular volunteers, the group signaled that becoming educated in informal venues and attending community events were just as important in terms of engagement with these issues. It also suggests that the Pub Theologians consider themselves part of a longer-term effort in terms of 
continuing their own education about these issues rather than considering it finished after making a donation or completing the presentation of their church service.

The group split the sermon writing responsibilities into three parts, both to give a wider range of representation of voices and to take the pressure off of one person having to be the only preacher. Tom summarized the facts, figures, and arguments of the books, Pat related the specific actions taken by the group as a result of their reading, and Harvey took up the finale of the sermon with a portion titled "What Can We Do." Harvey occupied a unique position in the group as its only AfricanAmerican member and its only member employed in the legal profession, as a public defender and criminal defense attorney. His life experiences, both personal and professional, led him to be completely unsurprised by the information in the books the rest of the group was finding quite shocking. Harvey and his wife Anita told many stories to the Pub Theologians about getting pulled over for "driving while black and white" over the course of their long marriage. Harvey also provided local legal context for many of the issues the group read about, and group members often asked him follow-up questions that applied his legal expertise to what they were reading in the books.

\section{"I'm Not Even an Advanced User": When Preaching to the Choir Leaves the Church Building}

The presumption that preaching to the choir is largely an insular activity does not take into account the unexpected ways that said preaching can leave the pulpit and the pews and take on different forms for different audiences. In this section I will show how two Pub Theology members, Tom and Michael, brought their religious literate activity outside the walls of the church, broadening the scope of their civic engagement in the process. Tom and Michael both reported completing a significant piece of writing in their workplaces that grew out of what they learned over the course of their year reading these texts. While acknowledging Gullette's point that plenty of older people get pushed out of their workplaces prematurely due to ageism and decline ideology, Tom and Michael use their positions of relative privilege within their fields to bring pieces of what they learned to a completely different audience from their fellow churchgoers. Both men were able to draw upon their years of previous work experience and familiarity with the expected genres in those settings in order to make their co-workers and others in their field aware of some of the concepts and ideas that their religious literate activity provided them.

Tom, a writer of one of the sermon parts and the de facto organizer of the Pub Theology group, wrote a speech about white privilege that he delivered to a large group of his co-workers at an annual conference that brought together employees from various satellite offices of his workplace. He said that as an "old-timer" in his position, he had attended many of these conferences over the years. This year's conference, though, was the first year that an upper-level administrator had asked him to lead a trust walk, which was intended to get the employees to reflect on implicit bias and white privilege. He said that, "To do that amongst my co-workers, to be the one putting myself out there, was a pretty significant stretch for me."

As part of his work leading the trust walk, Tom's boss asked him to write up an introduction to 
the activity to deliver orally to all of the employees present at the retreat before the activity began. He writes,

I have held the job title of Computer Training Specialist for almost 25 years now. Amazing. But during all that time, I have always maintained that I am not a computer expert, but just an advanced user trying to stay one step ahead of those I am training. Sometimes I have successfully stayed one step ahead. Other times not even close. I stand before you today feeling much the same talking about White Privilege. I am not an expert on this topic, I am not even an advanced user. I am sure many of you in this room have more knowledge on this topic than I. I have done some reading in the past two years that have [sic] caused me to look more openly at situations and people around me that live differently than me. As a white, straight, Christian male, at the top of the food chain I am beginning to better understand the privileges that have been bestowed upon me just because. I have a lot of work to do.

While the full length of Tom's remarks is about four times what is excerpted here, this introductory paragraph illustrates how he puts the commitments he made at church into discourse appropriate to his workplace. In drawing an analogy between being an "advanced user" in his position as a Computer Training Specialist but not an advanced user when it comes to white privilege, he opens up what might be a foreign or uncomfortable topic by using common professional language that most of the group would be familiar with and understand. While he briefly brings up that he is Christian, he does not directly reference the fact that this reading has been, for him, part of his religious commitment. While this sensitivity to the demands of a professional audience might seem an obvious move, the rhetor with religious commitments is often depicted by the field as being extremely heavy-handed and unable to rearticulate those commitments in different ways depending on the setting (e.g., Crowley). While this might hold true for some religious rhetors, it is worth considering the ways that others utilize different strategies in different settings to achieve similar ends. In Tom's case, his desired end of his literate activity, educating and persuading people to examine white privilege and its harmful effects, is the same in both the pulpit and at work.

While Tom is quite able to change up the content of his speeches to make them appropriate to each context, he reiterated that "again, after [supervisor] asked me to do that, I knew, I knew that I had to. I just knew I had to. You know, having come out of these book readings and the church service, if I was going to be true to myself and true to what I said, statements I made in church, I knew I had to do this." Tom makes clear that reading these books and sharing them first with a church audience had made his engagement with the topic both serious and heartfelt, and it also provided him with a sense of urgency for taking action on the topic in other areas of his life. Tom's experience illustrates that it is not simple to cordon off certain types of literate activity as religious and others as professional and still others as public or civic. In the tangle of practice that is Tom's life, he learned at church about a public or civic issue that then led to him writing a text that shares those commitments in a professional context. It can be difficult to measure and categorize something like Tom's speech at a work retreat as civic engagement, but this literate action clearly grows out of a desire to identify and address this issue of public concern. 
Michael similarly devoted a significant amount of time and energy to a professional activity based upon what he learned from participating in the Pub Theology reading group. Michael is semiretired, having transitioned out of working full time at his private therapy practice, but still gives consultations, participates in conferences, and creates short films dealing with the mental health issues of young children. He describes the film that he was inspired to make after reading these books, a film about the effects of having incarcerated parents on the mental health of young children: "This is the sixth in this particular series where I write what I think little kids think and what they

"While preaching to the choir can and does rally the faithful, it also has the potential to spill out into the world in surprising, ongoing ways. Tom and Michael's experiences suggest that when older people are allowed to shape the ways they civically engage according to their interests and proclivities, it will affect more spheres than either decline ideology or productive aging ideology allow."

would say if they were old enough to talk. I'm representing kids who don't talk yet or who talk in incoherent ways... I mean the whole idea came out of the Jim Crow book for me." As with his previous short films, he wrote the entire script himself and then collaborated with others for the voice acting and video editing. Though the idea came out of what he had learned about and committed to in the context of the church group, the final film script also does not highlight religious concerns and is usable by a variety of audiences. Michael has shared film in a community room in the local public library and at far-flung conferences and has been offering it for free on his website. He said that "This is the first one I've ever made that I'm offering for free, I feel that strongly about it."

What emerges from Michael and Tom's professional experiences after their Pub Theology Sunday service is civic engagement that is both richer and more complex than a one-size-fits-all ethos of volunteerism that has been foisted on older people. While each of their involvements looks quite different, they both utilize their past professional literate activities to bring their newfound (or at least newly reinvigorated) sense of civic engagement into conversations with their colleagues and others in their fields. Tom opens himself up in a new way to his coworkers, allowing them to see him in a different, more vulnerable, light, as an older person who is still actively learning and changing his mind about social justice issues. Michael reported that his film also brought him to a conference that put him in contact with people he would not have met otherwise, perhaps leading to future projects and collaborations. While preaching to the choir can and does rally the faithful, it also has the potential to spill out into the world in surprising, ongoing ways. Tom and Michael's experiences suggest that when older people are allowed to shape the ways they civically engage according to their interests and proclivities, more spheres are affected than either decline ideology or productive aging ideology allow.

\section{Conclusion}

Although the Pub Theologians initially fretted that their work with The New Jim Crow and Just 
Mercy would be a mere act of "preaching to the choir," their sustained engagement with these texts and the experiences that grew out of that sustained engagement shows just how complex preaching to the choir can be. Through drawing new connections while reading the local news, emotionally engaging and educating their congregation within the familiar genres of the Sunday service, and (for some) bringing the contents of Pub Theology to workplace genres, the Pub Theologians civically engaged with a social issue most of them had been largely unaware of when starting this journey. As a group of older adults, their work together pushes against a decline ideology that assumes older citizens to be disengaged from political involvement and current events, except as it involves themselves and their own benefits. Their work together also creates an alternative to the productive aging movement's one-size-fits-all volunteerism, illustrating how literate activity can itself be a form of civic engagement for older people.

As a group of progressive Christians, they demonstrate a way of expanding the map of how religious commitments can inform civic engagement that might eventually lead to more just outcomes for all. Neither I nor the Pub Theologians would argue that their prayers and sermons solve the problem of racism in the criminal justice system, or that everyone seeking to be involved in this or any social justice issue needs to come at it from a faith-based perspective. Their shared faith, however, did provide them a community to discuss these issues, a structure for sharing what they learned, and affective motivation to continue to engage in conversations that white people have found it all too easy to avoid. Though the presentation of their Sunday service on October 2, 2016, may have formally concluded the Pub Theologians' study of these two books, shortly thereafter, the group's numbers swelled. In response to their service and the contentious 2016 election, many more church members of a variety of ages began attending meetings, some evenings filling up all the furniture in their common room meeting area. They continue to choose books dealing with civic engagement and social justice. While the Pub Theologians do not think about the success of their group solely in terms of numbers, they were heartened to see the choir respond to their preaching by wanting to join the group and become engaged with these types of issues themselves. Literate activity is by no means salvation, but it's a start. 


\section{NOTES}

${ }^{1}$ I would like to take this opportunity to thank all of the members of Pub Theology for letting me spend my Monday nights eating popcorn with them while taking notes and recording. There would be no article without their generosity of spirit. Thanks are also due to Rev. Leah Robberts-Mosser for helping me coordinate fieldwork within the church as a whole. Lastly, Katherine Flowers, Michelle Martinez, Paul Prior, and the reviewers for this special issue all provided invaluable feedback at various points in the writing and revision process, for which I am grateful.

${ }^{2}$ Participants were given the choice to use their real name or a pseudonym on the IRB form in order to have the option to take credit for their written texts. Some Pub Theology members chose to use a pseudonym and others their given name.

${ }^{3}$ The transcription conventions used are as follows and are discussed at more length in Dressler and Kreuz:

- $\quad$ = indicates latched talk, a lack of a temporal gap between statements. $=$ signs indicate people talking quickly in succession

- [ ] indicate overlapping speech, or people speaking at the same time over one another

- $\quad$ underlining indicates a word or phrase that the speaker stressed or emphasized 


\section{WORKS CITED}

Adler, Richard P., and Judy Goggin. "What Do We Mean by 'Civic Engagement'?" Journal of Transformative Education 3.3 (2005): 236-53. Web. 13 May 2018.

Alexander, Michelle. The New Jim Crow: Mass Incarceration in the Age of Colorblindness. New York: New P, 2010. Print.

Bazerman, Charles. "Speech Acts, Genres, and Activity Systems: How Texts Organize Activity and People." What Writing Does and How It Does It: An Introduction to Analyzing Texts and Textual Practices. Eds. Charles Bazerman and Paul Prior. New York: Routledge, 2003. 30939. Print.

"Book of Common Prayer." The Encyclopedia of Christianity. Eds. Erwin Fahlbusch and Geoffrey W. Bromile. Grand Rapids, MI: Eerdmans, 2005. Print.

Bowen, Lauren Marshall. "Resisting Age Bias in Digital Literacy Research." College Composition and Communication 62.4 (2011): 586-607. Web. 12 Mar. 2018.

Brandt, Deborah. Literacy in American Lives. New York: Cambridge UP, 2001. Print.

Charmaz, Kathy. Constructing Grounded Theory. $2^{\text {nd }}$ ed. Los Angeles: SAGE Publications Ltd, 2014. Print.

Crowley, Sharon. Toward a Civil Discourse: Rhetoric and Fundamentalism. Pittsburgh: U of Pittsburgh P, 2006. Print.

Daniell, Beth. "More in Heaven and Earth: Complicating the Map and Constituting Identities." Mapping Christian Rhetorics: Connecting Conversations, Charting New Territories. Eds. Michael-John DePalma and Jeffrey M. Ringer. New York: Routledge, 2015. 243-61. Print.

DePalma, Michael-John, Jeffrey M. Ringer, and Jim Webber. "(Re)Charting the (Dis)Courses of Faith and Politics, or Rhetoric and Democracy in the Burkean Barnyard." Rhetoric Society Quarterly 38.3 (2008): 311-34. Web. 13 May 2018.

DePalma, Michael-John. "Re-envisioning Religious Discourses as Rhetorical Resources in Composition Teaching: A Pragmatic Response to the Challenge of Belief." College Composition and Communication 63.2 (2011): 219-43. Web. 12 Mar. 2018.

---. "Reimagining Rhetorical Education: Fostering Writers' Civic Capacities through Engagements with Religious Rhetorics." College English 79.3 (2017): 251-75. Web. 12 Mar. 2018.

Downs, Douglas. “True Believers, Real Scholars, and Real True Believing Scholars: Discourses of Inquiry and Affirmation in the Composition Classroom.” Negotiating Religious Faith in the Composition Classroom. Eds. Elizabeth Vander Lei and Bonnie L. Kyburz. Portsmouth: Boynton/Cook, 2005. 39-55. Print.

Dressler, Richard, and Roger Kruez. "Transcribing Oral Discourse: A Survey and a Model System." Discourse Processes 29.1 (2010): 25-36. Web. 3 Oct. 2018.

Filieule, Olivier. "Age and Social Movements." Wiley-Blackwell Encyclopedia of Social and Political Movements. Eds. David A. Snow, Donatella della Porta, Bert Klandermans, and Doug McAdam. Hoboken, NJ: Wiley Online Library, 2013. Web. 13 May 2018.

Gullette, Margaret Morganroth. Aged by Culture. Chicago: U of Chicago P, 2004. Print.

---. Ending Ageism, Or How Not to Shoot Old People. New Brunswick: Rutgers UP, 2017. Print.

Jones, Robert P. The End of White Christian America. New York: Simon and Schuster, 2016. Print.

Martinson, Marty, and Meredith Minkler. "Civic Engagement and Older Adults: A Critical Perspective." The Gerontologist 46.3 (2006): 318-24. Web. 13 May 2018.

Martinson, Marty, and Judith Halpern. "Ethical Implications of the Promotion of Elder Volunteerism: A Critical Perspective.” Journal of Aging Studies 25.4 (2011): 427-35. Web. 13 May 2018. 
Moss, Beverly J. A Community Text Arises: A Literate Text and a Literacy Tradition in AfricanAmerican Churches. Cresskill, NJ: Hampton, 2003. Print.

Mutnick, Deborah. "The Rhetorics of Race and Racism: Teaching Writing in an Age of Colorblindness." Literacy in Composition Studies 3.1 (2015): 71-81. Web. 8 May 2018.

Odell, Lee, Goswami, Dixie, and Anne Herrington. "The Discourse-Based Interview: A Procedure for Exploring the Tacit Knowledge of Writers in Non-Academic Settings." Research on Writing: Principles and Methods. Eds. Peter Mosenthal, Lynne Tamor, and Sean A. Walmsley. New York: Longman, 1983. 221-36. Print.

Prior, Paul. Writing/Disciplinarity: A Sociohistoric Account of Literate Activity in the Academy. Mahwah, NJ: Lawrence Erlbaum, 1998. Print.

Ringer, Jeffrey A. "The Consequences of Integrating Faith into Academic Writing: Casuistic Stretching and Biblical Citation." College English 75.3 (2013): 270-96. Web. 12 Mar. 2018.

---. "Working With(in) the Logic of the Jeremiad: Responding to the Writing of Evangelical Christian Students." College Composition and Communication 68.4 (2017): 629-54. Web. 12 Mar. 2018.

Rumsey, Suzanne Kesler. "Holding on to Literacies: Older Adult Narratives of Literacy and Agency." Literacy in Composition Studies 6.1 (2018). Web. 13 May 2018.

Solnit, Rebecca. "Preaching to the Choir." Harper's. Harper's Magazine Foundation, Nov. 2017: 5-7. Print.

Spindler, Mone. "Surrogate Religion, Spiritual Materialism, or Protestant Ethic? Three Accounts of the Function of Religiosity in Anti-Aging." Journal of Aging Studies 22.4 (2008): 322-30. Web. 13 May 2018.

Stevenson, Bryan. Just Mercy: A Story of Justice and Redemption. New York: Spiegel \& Grau, 2014. Print.

Strauss, Anselm L. Qualitative Analysis for Social Scientists. Cambridge: Cambridge UP, 1987. Print.

Trainor, Jennifer Seibel. "Critical Pedagogy's 'Other': Constructions of Whiteness in Education for Social Change." College Composition and Communication 53.4 (2002): 631-50. Web. 12 Mar. 2018.

---. “My Ancestors Didn't Own Slaves': Understanding White Talk about Race.” Research in the Teaching of English 40.2 (2005): 140-67. Web. 12 Mar. 2018.

---. Rethinking Racism: Emotion, Persuasion, and Literacy Education in an All-White High School. Carbondale, IL: Southern Illinois UP, 2008. Print.

Worth, Jan. "Student Pieties and Pedagogical Hot Spots: Mediating Faith-Based Topics in First-Year Composition." Writing on the Edge 14.1 (2003): 21-30. Web. 13 May 2018.

Winans, Amy E. "Local Pedagogies and Race: Interrogating White Safety in the Rural College Classroom.” College English 67.3 (2005): 253-73. Web. 12 Mar. 2018. 